\title{
LIBERALIZATION OF AIR TRANSPORT SERVICES UNDER THE FRAMEWORK OF THE WTO: CONFRONTING THE CHALLENGE OF THE TWENTY-FIRST CENTURY*
}

\author{
Zhao Yun*
}

1. Introduction

2. Reasons for including air transport services in the negotiations and relevant regulatory problems

2.1. Liberalization $v$. deregulation

2.2. General considerations for liberalization of air transport services

2.3. An appropriate arena for liberalization of air transport services

3. Present situation of air transport services under the framework of the WTO

3.1. An overview of the framework

3.2. Analysis of the WTO system for air transport services

3.2.1. General analysis of the GATS framework for air transport services

3.2.2. An analysis of the Annex on Air Transport Services

3.2.3. Other commitments of the Member States

3.2.4. Dispute settlement

3.3. Comments on the Annex on Air Transport Services

4. The framework for future negotiations on air transport services

4.1. General observations

4.2. Possible areas for further liberalization in the next Round

4.2.1. Clarification of certain terms

4.2.2. Applicable general principles and traffic rights

4.2.3. Possible services for negotiations in the next Round

4.2.3.1. Freedom of transit

4.2.3.2. Non-scheduled (Charter) flights

\footnotetext{
- This is a revised version of a paper that was awarded the 2001 Sata Prize for young Asian scholars in the field of international law. The prize is, whenever possible, awarded every year by the Foundation for the Development of International Law in Asia (DILA).

** As of 2002, City University of Hong Kong.

Asian Yearbook of International Law, Volume 8 (B.S. Chimni et al., eds.)

(C) 2003 Koninklijke Brill NV. Printed in The Netherlands, pp. 3-36.
} 
4.2.3.3. Air cargo services

4.2.3.4. Ownership and control

4.2.3.5. Ground handling

4.2.3.6. Aircraft leasing

4.2.3.7. Other services and onwards

5. Conclusion

5.1. Tentative evaluation

5.2. Implications for developing countries

5.3. Closer cooperation between the ICAO and the WTO

5.4. Epilogue

\section{INTRODUCTION}

Commerce, communications and national defence are heavily dependent on an efficient and reliable air transportation system. ${ }^{1}$ Consequently, this has traditionally been controlled by each national State and is based on the concept of the sovereignty of the State over its airspace. ${ }^{2}$ However, commercialization has led to a reconsideration of the monopoly. This was particularly true for more aviation-oriented states, like the United Sates of America. First, it had occurred domestically under the close supervision of national agencies with the purpose of liberalizing services, but slowly likeminded States combined to try to improve the system. Bilateral agreements were thus created and the International Air Transport Organization (the ICAO) subsequently came into being, charged with the vital task of coordinating the aviation policies of its Member States. Even so, liberalization of air transport services was not then generally accepted among most States.

Against this backdrop the US in the late 1970s initiated a process of deregulation in accordance with its long-held "open skies" philosophy. ${ }^{3}$ This process led to markedly increased US profits in the air transport markets and was, consequently, introduced into the various bilateral air transport agreements of the US. The process was followed in other parts of the world, most

1 O.J.LISSITZYN, International Air Transport and National Policy (1942) 18-19, at 38.

2 As early as the Paris Conference of 1910 there was already a tendency in favour of it. In the 1944 Chicago Convention the concept was regarded as one of the fundamental principles in air transport. Art. 1 of the Convention recognizes that every state has complete and exclusive sovereignty over the airspace above its territory, this being the expression of customary international law. See B.CHENG, The law of international air transport (1962) 120; id., "Recent developments in air law", 9 Current Legal Problems (1956) 208; G.SCHWARZENBERGER, International Law, Vol.1: International law as applied by international courts and tribunals, 3d. edn (1957) 226; A.D.McNAIR, The Law of the Air, 2nd edn (1953) 8; L.WEBER, "EEC air transport liberalization and the Chicago Convention", 17 Annals of Air and Space Law (1992) 247.

3 See further B.STOCKFISH, "Opening closed skies: the prospects for further liberalization of trade in international air transport services”, 57 Journal of Air Law and Commerce (1992) 600. 
significantly in the European Community (EC). ${ }^{4}$ The system during that period could still be characterized as bilateralism or, at best, regionalism, as shown by the negotiations among the EC Member States.

The situation has changed considerably since then. For the time being the various forces at work are still pulling in opposite directions, but both national regulation and ICAO control may be eroding as a result of collectivization and thus the time may have arrived for the ICAO to adjust its policies, ensuring that the worldwide uniformity and freedom from political considerations essential for achieving proper standards of safety in civil aviation $^{5}$ also conform to the world trend of liberalization. It was not until the launch of the Uruguay Round of the General Agreement on Tariffs and Trade (GATT), however, that air transport services were discussed at a more universal multilateral level.

Among the various agreements reached at the Uruguay Round, the General Agreement on Trade in Services (GATS) stands out distinctly as covering all service-related issues. Air transport services were contemplated to be covered and a special Annex on the matter was later appended to the GATS. Disappointingly, however, only a very limited number of areas was covered and it is not to be expected that this situation will improve in the near future under the GATS institutional umbrella. The Annex was up for review in a round of negotiations that was scheduled to be launched in late 1999 at Seattle yet was abandoned as a result of strong opposition from different interest groups.

The present paper purports to examine the effects of the Uruguay Round on the matter of air transport services and their further liberalization. It will first address the motives underlying the inclusion of air transport services in the multilateral trade negotiations (section 2). The next section (3) will be devoted to the examination of the relevant WTO rules dealing with the liberalization of air transport services; after which (in section 4) we shall proceed to comment on possible areas of further liberalization in the WTO framework. Finally, the paper will evaluate liberalization within the WTO framework and offer some tentative conclusions.

\footnotetext{
4 The US-style liberalization was characterized by a wave of new entrants, unbridled competition, shake-outs, mergers, bankruptcies, the formation of hubs and spokes, increased airline concentration leading to the creation of mega-carriers, and most recently, the challenge of low-cost, no-frills transport which is forcing mega-carriers to respond by adopting similar measures. See further J.M.BRUNEAU, "Concentration within the U.S. airline industry: a 'natural phenomenon' or an 'ordinary' monopoly/oligopoly resulting from the behaviors of competitors?", 17 Annals of Air and Space Law (1992) 123. However, the EU opted for another type of liberalization, so-called "controlled liberalization", characterized by a gradual relaxation of routes and fares controls.

5 A.KEAN, "Air law past and future: the challenges of the XXIst century", 17 Annals of Air and Space Law (1992) 13.
} 


\section{MOTIVES UNDERLYING THE INCLUSION OF AIR TRANSPORT SERVICES IN THE NEGOTIATIONS AND THE RELEVANT REGULATORY PROBLEMS}

Air transport services as an important element of the economic infrastructure were included in the GATS and further elaborated in a special Annex. Against the planners' hopes and expectations, however, only a marginal part of the sector was covered by the agreement. There existed strong opposition to the air transport services' being included into plurilateral negotiations or, more specifically, into the WTO framework.

\subsection{Liberalization versus Deregulation}

The retreat of national governments from intervention in the national economy has been a significant trend in recent years. This phenomenon is widely termed "liberalization" or "deregulation". It was essentially meant to leave economic performance totally or at least increasingly to the manipulation of market forces and proved successful, as shown in the experience of post-war economic development.

Liberalization and deregulation are seemingly identical concepts. However, it is necessary to draw a distinction between them when discussing issues from a plurilateral angle. Deregulation of various industries, governed by a system of economic, public utility-type government regulations, is first and foremost a US phenomenon that began to appear in the mid-1970s ${ }^{6}$ and gained pace in other States at whatever respective stage of economic development. A State has the right to decide for itself upon the issue of deregulation and act accordingly. It is both within its sovereignty and internationally a purely unilateral act, though sometimes drawing protest from other States. ${ }^{7}$

It might be said that deregulation takes the form of a network of bilateral or regional agreements; it is here suggested, however, that the applicability of international agreements in the municipal sphere depends on relevant

\footnotetext{
6 P.HAANAPPEL, "Air transport deregulation in jurisdictions other than the United States", 13 Annals of Air and Space Law (1988) 79; See also idem, "Deregulation of air transportation in North America and Western Europe", in J.STORM VAN 'S GRAVESAND and A.VAN DER VEEN VONK (eds.), Air worthy (1985) 89, 93, and id., "IATA tariff co-ordination and competition law", 20 Air \& Space Law (1995) 82. From 1946 until approximately thirty years later, when the airline deregulation movement was initiated, the international air transport pricing system was essentially one of regulated competition. Note, however, the difference from the EU-type of controlled liberalization, see supra n.4. 7 The newly revised Enforcement Guidelines of the US Dept. of Justice extend extraterritorial jurisdiction of the US antitrust laws far beyond any previously seen or known. In line with this position, two recent US court cases are noteworthy. In Virgin Atlantic Ltd. v. British Airways plc, as well as in US v. General Electric, and in Eskofot v. Du Pont, US courts accepted jurisdiction in essentially Europe-related anti-trust suits. See further L.WEBER, "Modern trends in the antitrust/ competition law governing the aviation industry", 20 Air \& Space Law (1995) 101-109.
} 
national legislation on and for their transformation into national law or their determination as being directly applicable. In other words, the applicability of agreements depends on the consent of the national authority. Therefore, deregulation normally has its effects in the context of one specific jurisdiction, that is, domestically, e.g. within the US (or within the EC market). ${ }^{8}$ Meanwhile, spreading the deregulation gospel at the international level became an instrument of national policy with the purpose of breaking through the long-established negotiated and mutually agreed system of mutual advantages and common government-sanctioned rules. ${ }^{9}$

As to liberalization: a State may, of course, decide on its own whether or not to adhere to a liberalization policy. However, liberalization may also be realized in other ways, namely, bilaterally and multilaterally. Instead of unilaterally introducing measures of liberalization, a State may negotiate bilateral or multilateral measures with other interested States and achieve agreement on mutual benefits. The effect of liberalization could thus be more extensive. This has been proven by the experience of liberalization through the GATT. Contrary to deregulation as a national policy-setting act, liberalization is a universal trend that is difficult for individual governments to resist. As already referred to above, in the field of air transport services liberalization came initially in the form of unilateral deregulation in the US, ${ }^{10}$ while multilateral liberalization formally entered the stage only at the Uruguay Round of negotiations.

Liberalization as a process usually stems from deregulation. Deregulation of the air transport industry, in its various forms, results in the creation of international and large domestic air transport markets that are more competitive than before. This induces national governments to liberalize beyond national borders in other than a unilateral way. Liberalization per se does not, however, necessarily imply deregulation in the strict sense of the word; it could imply introducing new regulations on a voluntary basis. Regulation may be conducive to realizing liberalization. One should not set aside all

\footnotetext{
8 See further H.A.WASSENBERGH, "New aspects of national aviation policies and the future of international air transport regulation", 13 Air Law (1988) 20. In Europe, however, the term air transport 'liberalization' rather than 'deregulation' is consistently used. See P.HAANAPPEL, "Europe 1992 and airline (de)regulation", 17 Annals of Air and Space Law (1992) 272; id., "Recent regulatory developments in Europe", 16 Annals of Air and Space Law (1991) 107, note 1. This also proves that 'deregulation' is used within a national context. The use of the term 'liberalization' in the context of Europe implies that the aim of one EEC market has not yet been achieved, though it is one of the major players in world commerce. For an analysis of an interesting recent case on the external competence of the European Community, see C.RIVOAL, "Opinion of the European Court of Justice on the WTO Agreement (15 November 1995)", 21 Air \& Space Law (1996) 25-27.

9 K.HAMMARSKJOLD, "Deregulation - idealism, ideology or power politics? Focus - Europe", 12 Annals of Air and Space Law (1987) 66.

${ }^{10}$ It was followed by the United Kingdom, with the creation in 1971 of the Civil Aviation Authority (CAA) by the Civil Aviation Act. This was some kind of forerunner of a domestic airline deregulation outside the US.
} 
regulations merely for the sake of deregulation, but instead abolish only those that prevent or hinder the development of competition. The final conclusion is that the ultimate goal of deregulation is liberalization, a much broader concept than "deregulation".

\subsection{General considerations for liberalization of air transport services}

Air transport services have traditionally been under the exclusive control of States because of the various considerations of vital national interests involved. Most of all, the firmly held principle of national sovereignty over airspace has succeeded in deterring liberalization, while considerations of national security have also served as an effective excuse. However, with the expansion and maturity of the air transport industry, new trends favouring liberalization have arisen.

First, technological development has brought about drastic increases in aviation ability and capacity. The evolving technology of air transport was one of the key factors that led to the need for regulatory adjustment and spurred fundamental economic change,$^{11}$ such as the fact that the success of JetBlue Airways threatens further to undermine the network airline pricing model. Startling developments in the field of aeronautics have challenged the effectiveness of State sovereignty in this area. The use of telecommunication satellites and the incorporation of the ubiquitous electronic developments have played their role in the modernization of the air transport industry. Actually, from a technical point of view, technical borders between states no longer exist.

Secondly, air transport serves as a kind of infrastructure for other services, such as tourism and commercial transactions, which depend on good transport conditions. To take another example: we have witnessed the rapid development of electronic commerce through the Internet in recent years, simplifying some ways of doing business and facilitating direct business with the consumer. Yet these business transactions do not end with the web-site operation, as they still require the transportation of the goods to the consumer. The goal of electronic commerce is achieved only when the goods reach the consumer properly and more expeditiously. Without an adequate transport web and, even more significant, a liberalized and reliable transport system, the rapid and healthy development of electronic commerce is in fact unthinkable. The same is the case with other services.

11 L.GIALLORETO, "A retrospective on the reinvention of international civil air transport economic regulation: circa 1994-2004", 19 Annals of Air and Space Law (1994) 327. See also P.FLINT, "Lessons to be Learned and Unlearned", http://www.atwonline.com. 
In modern society, air transport is becoming increasingly important, compared with other means of transportation. ${ }^{12}$ While the regulation of air transport has initially occurred in isolation from that of other modes of transportation, the economic developments between 1944 and 1994 have brought air transport into a broader, common, transportation context. ${ }^{13}$ Accordingly, the liberalization of air transport has become very important also for the liberalization of other modes of transportation; a lack of liberalization in one sector hampers the liberalization of other services. In fact, progress and development in the air transport sector has often served as a catalyst for greater economic prosperity, both domestically and internationally. ${ }^{14}$

Thirdly, the success of liberalization in the US and other Western States has offered a good example. The economic prosperity brought about by liberalization has attracted many other states to adopt the same ideas and policies, and the resulting internationalization and globalization of trade in goods and services has become a major theme in international economics. For its part, this development has further strengthened the vital role of air transport services in the national economy. On the one hand, the increased prosperity implies greater utilization and employment opportunities; on the other hand, it means a greater dependence of various economic sectors on air transport services.

Fourthly, the ICAO became aware of the need to include the economic side of the air transport sector into its multilateral regime. In April 1992, the World-wide Air Transport Colloquium was convened by the ICAO to allow the exchange of views on a number of fundamental issues, including on the possible application to international air transport of trade concepts and principles. While there was still some support for bilateralism, high expectations were already expressed in favour of supplementing it with multilateral agreements. ${ }^{15}$ Later on, in a 1994 colloquium, the idea of multilateral arrangement received wide support from representatives of various States. Since then, the ICAO has been working vigorously to realize the liberalization of the air transport sector.

Finally, the significance of market forces and the theory of economic efficiency are being widely acknowledged. Governments have increasingly

\footnotetext{
12 Both shippers and passengers now rely to a much larger extent on air transport services, as a result of changing production methods of goods and the development of tourism.

${ }^{13}$ See further P.B.LARSEN, "Air transportation in an intermodal setting", 21 Annals of Air and Space Law (1995) 431.

14 P.S.DEMPSEY, "The prospectus for survival and growth in commercial aviation", 19 Annals of Air and Space Law (1994) 163-164.

${ }^{15}$ See the outcome of the ICAO World-Wide Air Transport Colloquium of April 1992, A29-WP/32, $\mathrm{EC} / 5$, at 4 . The Colloquium reiterated the inapplicability of the MFN Principle, but did bring about a perception of changes towards greater liberalism, which strongly implied multilateralism in air transport.
} 
come to recognize the direct benefits of allowing airlines to operate freely in a market-responsive manner, and the indirect benefits that will spin off for other industries. ${ }^{16}$

An overwhelming impetus for trade liberalization comes from the necessity for countries to improve the functioning of their services market, and thus to raise economic efficiency and promote growth and development. ${ }^{17}$ Further economic development requires decreasing costs and increasing reliability of transportation. A proper economic climate and improvement in transportation can become catalysts for economic expansion. ${ }^{18}$ The market forces, as an invisible hand, adjust supply and demand and have compelled the aviation industry ${ }^{19}$ as well as the State aviation authorities to increase their efforts to succeed in the market place. ${ }^{20}$ Formerly, political considerations took priority in matters of type of services, quantity, and so on, thereby sacrificing economic efficiency. This was apparent in the stringent national regulations. Considerations of so-called protection of national security raised costs for domestic consumers and thus rendered domestic services less competitive. This adversely affected the air transport suppliers' ability to make profits and they in turn grew reluctant to improve their services.

With the initiation of liberalization by the US, the question of how to attain maximum economic efficiency in air transport has been taken to a new stage. More and more people readily accept the idea of letting private entrepreneurs free to do what they can do in a much better, cheaper and more efficient way, to the consumer's benefit. ${ }^{21}{ }^{22}$

To sum up, it hardly seems necessary to discuss whether to liberalize air transport or not, thus we shall focus our attention instead on finding an optimum way of liberalizing.

16 G.LIPMAN, "Multilateral liberalization - the travel and tourism dimension", 19 Air \& Space Law (1994) 152.

17 A.SAPIR, "The General Agreement on Trade in Services: from 1994 to the year 2000", 33 Journal of World Trade Law (1999) 63.

${ }_{18}$ Transportation and economic development - a summary of key issues being explored on transportation options and economic development - Wisconsin Translinks 21, see http://www.bts.gov/ smart/cat/ted.html.

19 The airline industry will strive for the optimum optimorum that, due to market dynamics, represents a moving target. See H.B.ROOS and N.W.SNEEK, "Some remarks on predatory pricing and monopolistic competition in air transport", 22 Air \& Space Law (1997) 156.

${ }^{20}$ See further K.BOCKSTIEGEL, "Current challenges in the legal regulation of civil aviation", 21 Annals of Air and Space Law (1995) 139.

${ }^{21}$ K.C.BERNAUW, "Air courier services and the debate on the postal monopoly", 16 Annals of Air and Space Law (1991) 29.

${ }^{22}$ Concerning fair allocation of scarce resources, in particular allocation of slots, see P.HAANAPPEL, "Airport slots and market access: some basic notions and solutions", 19 Air \& Space Law (1994) 205. 


\subsection{An appropriate arena for the liberalization of air transport services}

While many, if not most, States have come to adhere to a common pursuit of liberalizing air transport services, the remaining issue is: by what means: unilateral, bilateral or multilateral?

The unilateral way has been used by almost all States, with any differences in application lying in the extent of liberalization. The beneficial effects have been rather restricted, since arrangements on an international topic imply, as a rule, some balancing of mutual rights and obligations, while usually a State will not unilaterally confer a benefit on other States. Consequently, there has been a preference for bilateral means.

As we have seen, multilateral efforts to introduce liberalization into the field of air transport services have not succeeded. The 1944 Chicago Convention $^{23}$ failed to bring about a common commercial framework. ${ }^{24}$ Instead, the bilateral way remained a great success. ${ }^{25}$ In the bilateral system both parties treat each other as equals. Typically, there are no special concessions making allowances for the respective stage of economic development of the parties. ${ }^{26}$ Only when the interests of the two States coincide will they reach an agreement. The application of bilateral agreements enables each State to protect its own airlines to whatever extent it considers necessary and to the extent permitted by its wider interests.

Differences in the contents of the various bilateral air transport agreements have given rise to inequalities in the levels of liberalization in respective air transport services, in the sense that the agreements vary from country-pair to country-pair, reflecting in each case the specific balance of interests and power between the two states concerned. ${ }^{27}$ Such an outcome shows the valuable nature of traffic rights.

${ }^{23}$ Convention on International Civil Aviation, 7 December 1944, 15 UNTS 295, ICAO Doc. 7300/6, 1944 CTS 36. The Convention entered into force on 4 April 1947 and is presently adhered to by approximately 175 States.

${ }^{24}$ Art. 6 of the Chicago Convention was regarded as the starting point for the present restrictive bilateralism in the exchange of operational and traffic rights for international scheduled air services. See further H.A.WASSENBERGH, "Parallels and differences in the development of air, sea and space law in the light of Grotius' heritage", 9 Annals of Air and Space Law (1984) 163.

${ }^{25}$ The first liberal bilateral air transport agreement was the Protocol to US-Netherlands Air Transport Agreement of 1957, 29 UST 3089, TIAS 8998 (entered into force on 31 March 1978). The US concluded liberal agreements with a wide variety of countries between 1978 and 1982-83. Later several countries other than the US began to adopt bilateral agreements as a possible negotiating strategy. Up till now there are almost 3000 bilateral agreements.

${ }^{26}$ R.EBDON, "A consideration of GATS and of its compatibility with the existing regime for air transport", 20 Air \& Space Law (1995) 71.

${ }^{27}$ Remarks by K.VEENSTRA, Deputy Secretary General of AEA, at the European Services NetworkMeeting of 26 January 1999. 
Until recently, the bilateral method has been regarded as the most appropriate means of liberalization of air transport services, given its specific features. It is now being realized, however, that it can be time-consuming, causing unbalanced structures in international air transport; consequently, the bilateral system has come under increasing strain in recent years. It no longer responds adequately to the challenges of a fast changing international business environment and a rapidly integrating and globalizing market. ${ }^{28}$ The adoption of "open skies" policies and the progressive liberalization of the international regulatory regime of air transportation have begun to cause some erosion of the traditional bilateralism. ${ }^{29}$

In its stead a multilateral means was suggested, combining the liberal air agreements into one multilateral agreement among the parties to such liberal bilateral air agreements. Nevertheless, such a multilateral agreement may still prove to be some sort of multilateral Bermuda 4 agreement. ${ }^{30}$ When we look for the essence of such an arrangement, it is at best a loose regional liberalization; at worst, it is of various bilateral agreements a combination that differs little from genuine bilateralism. While acknowledging its advantages, we cannot deny that it would still entail the shortcomings of bilateralism. ${ }^{31}$

In fact, efforts to liberalize air transport services in a multilateral framework have continued since the 1940s, as the construction of a seamless and waterproof structure for the future of international air transport is possible only by multilateral means. At the time of the drafting of the Chicago Convention the ICAO was suggested as the arena for the accomplishment of this task; efforts to find a multilateral solution to the problem of the economic regulation of air transport failed in $1947 .{ }^{32}$ Paradoxically, should the ICAO truly have succeeded, this would have created significant institutional obstacles to the comprehensive liberalization of trade in services. ${ }^{33}$ More important

28 A.GIL, "The outcome of the $4^{\text {th }}$ ICAO Air Transport Conference and its implications for airports", 20 Air \& Space Law (1995) 76.

29 H.A.WASSENBERGH, "The 'sixth' freedom revisited", 21 Air \& Space Law (1996) 285.

30 See H.A.WASSENBERGH, "New aspects of national aviation policies and the future of international air transport regulation", 13 Air Law (1988) 31-32. The so-called Bermuda Formula is actually a gradual liberalization of the bilateral system.

31 Concerning the shortcomings of the bilateralism, see ICAO Working Paper No.WATC-5.1 of 6 April 1992. See also H.A.WASSENBERGH, "Commercial aviation law 1998, multilateralism versus bilateralism", 23 Air \& Space Law (1998) 23-24.

32 See further H.A.WASSENBERGH, "The future of multilateral air transport regulation in the regional and global context”, 8 Annals of Air and Space Law (1983) 263-264; see also Doc.5230, A2-EC/10, (ICAO Records of the Commission on Multilateral Agreement on Commercial Rights, Geneva 1947).

${ }^{33}$ If this sector were left to the disposal of a special agency instead of falling under a general regime, the same exception could be claimed by other services sectors. For example, The International Telecommunications Union could be given charge of the telecommunications services. This could lead to the breakdown of the GATS structure. See further R.JANDA, "Passing the torch: why ICAO should leave economic regulation of international air transport to the WTO", 21 Annals of Air and Space Law (1995) 416. 
is the fact that the ICAO has, during its history, successfully coordinated technical policy, even though not being directly involved with the economic aspects of air transport.

On its part the WTO, with the GATS in particular, has through its activities developed a vast body of experience in dealing with the commercial transactions in many sectors. Other modes of transport have already been successfully included in the GATS, and the losses of one branch would certainly constitute a benefit to other branches ${ }^{34}$ Actually, the Annex on Air Transport Services specifies that the Council for Trade in Services shall periodically review developments and operations with a view to considering the possible further application of the GATS in the sector. ${ }^{35}$ In its turn, GATS will, through the WTO dispute settlement mechanism, generate precedent and procedure of great relevance to air transport liberalization. ${ }^{36}$

\section{THE PRESENT SITUATION OF AIR TRANSPORT SERVICES WITHIN THE FRAMEWORK OF THE WTO}

\subsection{An overview of the framework}

Serving as an important infrastructure for other services, air transport services are inseparable from trade in goods. Although the GATT, as the predecessor of the WTO, dealt with the liberalization of trade in goods and although it was not specifically intended to regulate air transport services, it did to a certain extent touch on this sector, such as in its impact on the trading of aircraft. Some "horizontal" WTO initiatives are important for the air transport area, such as trade facilitation, ${ }^{37}$ competition, the environment, and government procurement. ${ }^{38}$ Liberalization of these areas will have a significant impact on the air transport services, thus due account is to be taken of the areas when dealing with the liberalization of air transport.

The GATS, although being the agreement specifically to deal with all sorts of services, is currently excluded from the regulation of air transport services except the items covered by the Annex on Air Transport Services. This Annex limits the application of the GATS to three types of services in the sector, although the member states are free to offer further commitments,

\footnotetext{
${ }^{34}$ G.WINTER, "On integration of environmental protection into air transport law: a German and EC perspective”, 21 Air \& Space Law (1996) 141.

${ }^{35}$ See para.5 of the Annex.

${ }^{36}$ Loc.cit.n.33.

${ }^{37}$ See Trade facilitation, issues relating to the physical movement of consignments (transport and transit) \& payment, insurance and other financial questions affecting cross-border trade in goods in the European Community (Council for Trade in Goods of World Trade Organization, G/C/W/133 (98-4853), 3 December 1998).

${ }^{38}$ GATS 2000 and Air Transport Services (European Commission non-paper).
} 
which then become binding upon them. Thus, the present legal framework is rather loose and we are still far from full liberalization of air transport services under the WTO. In the following discussion, we shall analyse the agreed rules and arrangements in order to discern how trade in this sector is so far being carried out.

\subsection{General analysis of the WTO system for air transport services}

\subsubsection{General analysis of the GATS framework for air transport services ${ }^{39}$}

Contrary to trade in goods where there are two types of visible barriers that are easy to detect, trade in services is characterized by a vast number of invisible barriers that need further effort in their identification and, once identified, need further effort to have the existing legal regime modified. This means that liberalization in services will have to proceed gradually and must include mutual benefits to all relevant parties: the process takes time and persuasion, which is the reason why the instant liberalization of the whole of a specific sector is usually met with opposition. Accordingly, the negotiators arrived at a model that, while based on the GATT, was in certain ways quite different, reflecting the intangible and non-storable nature of services.

The GATS consists of three pillars: the Agreement itself, the Sectoral Annexes, and the Schedules outlining each member's negotiated commitments to liberalize trade in services. ${ }^{40}$ It formally comprises twenty-nine articles and is intended to cover all tradable services supplied at the international level by any of four modes of delivery. ${ }^{41}$

Two essential provisions form the basis of the GATS: the most-favoured nation (MFN) principle (Article II) and the transparency rule (Article III). The MFN principle prohibits discrimination between suppliers of foreign services and guarantees that any favourable treatment granted to any one country shall also automatically be granted to all other member states. However, although MFN is a general obligation, the GATS contains an Annex

39 For a more detailed description of the GATS, see further Y.ZHAO, "The commercial use of telecommunications under the framework of GATS", 24 Air \& Space Law (1999) 311-316.

40 See further the presentation by G.SAMSON, Director of the Group of Negotiations on Services Division, General Agreement on Tariffs and Trade, at the World-Wide Air Transport Colloquium, Montreal, 6-10 April 1992, at 3.

${ }^{41}$ Under its Art.I the GATS categorizes the supply of services into four different modes of delivery: the supply of a service across the border can take place by movement of the service itself to the customer (mode 1: cross-border supply), or by movement of the customer to the supplier (mode 2: commercial presence), or by the establishment of a commercial presence in a foreign country (mode 3: consumption abroad), or through the movement of natural persons (staff) on a temporary basis (mode 4). See www.wto.org/wto/new/guidel.htm. According to the WTO Secretariat the most important mode of supply is mode 3. See op.cit.n.37. See also Air transport services (Background note by the Secretariat, Council for Trade in Services, WTO, S/C/W/59 (98-4346) of 5 Nov.1998. 
allowing for exemptions. Thus, the coverage of the MFN principle is determined by a so-called negative list. ${ }^{42}$ The transparency rule requires Member States to make their rules on, and measures affecting, trade in services publicly known or easily available, thus reducing in international transactions any uncertainty that could defeat the purpose of the regulation. ${ }^{43}$

There are three other liberalization provisions, namely, the Market Access principle (Article XVI), the National Treatment principle (Article XVII) and the Domestic Regulation rule (Article VI). The first principle obliges Member States to open their domestic markets to all services suppliers; the second principle obliges Member States to grant all foreign services suppliers the same treatment as accorded to domestic suppliers, while the third principle prohibits future introduction of discriminatory measures against competition in the markets to the freedom of which the State concerned has committed itself. It is to be noted that the market access and national treatment obligations apply only to the services listed in the schedule of each Member State. The Member States are free to decide upon their respective scales of commitments in the schedule, but once this is done, the Member in question may not later take a contrary action. This freezing mechanism in fact acts as a guarantee of gradual liberalization.

Besides the above provisions, there are twelve other provisions setting out "general obligations and disciplines". Certain obligations are of particular relevance to air transport services. First of all, the Economic Integration provision (Article $\mathrm{V}$ ) allows Members to enter regional agreements on the liberalization of trade without extending the created right to preferential treatment to other Member States. However, one precondition for this entitlement is that the agreement has as its purpose the furthering of meaningful economic integration and progressive trade liberalization. Thus, in the case of the EU, liberalization measures taken in respect of relations among its Members inter se would not be extended to other Members of GATS.

Secondly, the Mutual Recognition provision (Article VII) allows groups of Members to conclude agreements (or act unilaterally) towards the recognition of another State's domestic standards or criteria for the authorization, licensing and certification of service suppliers as being equivalent to its own. This provision is most closely relevant to regulations in the field of air transport relating to safety issues such as leasing, maintenance and repair, and crew and pilot training services, for example. It allows Member States to keep improving safety standards without imposing on them the obligation of extending recognition to other Members whose standards do not as yet

\footnotetext{
42 A member state may maintain a measure that existed at the entry into force of the GATS although inconsistent with the MFN treatment, provided that such a measure is listed in, and meets the conditions of, the Annex on Article II Exemptions. See B.Hoекman and M.KosteCKI, The political economy of the world trade system (1995) 131.

${ }^{43}$ P.NICOLAIDES, "Economic aspects of services: implications for a GATT Agreement", 23 Journal of World Trade Law (1989) 131.
} 
meet the same requirements regarding levels of protection. Besides, the provision has the merit of spreading such higher safety standards by prescribing the possibility of accession by other interested Member States.

Thirdly, the Monopolies and Exclusive Services Providers provision (Article VIII) requires reasonable and non-discriminatory access to service suppliers. Closely connected with this provision, the (Restrictive) Business Practices provision (Article IX) recognises that certain business practices may restrain competition and thereby restrict trade in services. This is especially relevant to the field of computer reservation systems. Such practices, which may include subsidies and government procurement, should not be adopted or should be eliminated, as the case may be.

The above provisions set out in general terms an approach on how to liberalize services while leaving specific areas for further negotiations. This is in accordance with the general idea of gradual liberalisation. In order to achieve a prompt adoption of the GATS, some exemptions were accepted, like the MFN exemption, environment considerations, etc. Furthermore, the GATS contains several provisions relating to possible exceptions: Emergency safeguard measures (Article X); Restrictions to safeguard the balance of payments (Article XII); Security exceptions (Article XIV bis). All these exemptions and exceptions, however, may be claimed only on very limited grounds. ${ }^{44}$

\subsubsection{An analysis of the Annex on Air Transport Services}

During the Uruguay Round of negotiations, it was felt that special features characterized air transport and that these would prevent its inclusion within the general and unconditional application of the GATS discipline. ${ }^{45}$ Thus, a separate Annex on Air Transport Services was drawn up to accommodate the needs of the members. ${ }^{46}$ It forms an integral part of the GATS and clearly sets out the scope of the Agreement in the field of air transport. Since the GATS is the first successful multilateral liberalization effort in this sector,

\footnotetext{
44 For example, the Annex on Article II Exemptions allows the exemptions only at the entry into force of the Agreement and these exemptions shall be reviewed within no more than five years, should not exceed ten years and shall be subject to negotiation in subsequent trade-liberalizing rounds.

45 GATS 2000 and air transport services (UK Dept. of Environment, Transport and the Regions, $<$ http://www.aviation.detr.gov.uk/consult/gats2000/index.htm>.

${ }^{46}$ For detailed description of national commitments, see ICAO Working Paper A32-WP/52, EC/5, Addendum No.1, of 4 September 1998.
} 
one paragraph of the Annex is dedicated to a system of periodic review. ${ }^{47}$ The Annex also provides for the settlement of disputes in the sector.

The Annex consists of six paragraphs. The first three paragraphs define the scope of the Annex and of the GATS with regard to trade in air transport services. Paragraph 1 establishes the primacy of existing bilateral or multilateral agreements that were in effect on the date of entry into force of the WTO agreement, over the GATS. This is based on the consideration that the present supply of air transport services is governed by some 3000 bilateral agreements worldwide, covered by ICAO.

Paragraphs 2 and 3 are closely related. Paragraph 2 explicitly excludes the application of GATS to measures affecting traffic rights and services directly related to the exercise of traffic rights, except as provided in Paragraph 3. This latter paragraph on its part lists three measures covered by the GATS: aircraft repair and maintenance services, the selling and marketing of air transport services, and computer reservation system (CRS) services. This means that the general obligations and principles of the GATS are to apply to these three activities unless a Member claims exemption particularly under the Annex on Article II Exemptions.

Paragraph 6 of the Annex on Air Transport Services provides definitions of the three categories of services in the field of air transport to which the GATS is to apply. "Aircraft repair and maintenance services" are defined in sub-paragraph (a) as meaning "such activities when undertaken on an aircraft or a part thereof while it is withdrawn from service and do not include so-called line maintenance". This corresponds to what is meant in the industry by the "MRO" concept: maintenance, repair and overhaul. Sub-paragraph (b) defines the "selling and marketing of air transport services" as "opportunities for the air carrier concerned to sell and market freely its air transport services including all aspects of marketing such as market research, advertising and distribution. These activities do not include the pricing of air transport services nor the applicable conditions". It follows from this definition that activities carried out by computer reservation system (CRS) are not covered. Finally, "Computer Reservation System" (CRS) services are defined in subparagraph (c) as "services provided by computerized systems that contain information about carriers' schedules, availability, fares and fare rules, for which reservation can be made or tickets may be issued". The CRS enables

\footnotetext{
${ }^{47}$ According to the provision, a periodic review of the air transport services (as listed in the Annex) and the operation of the Annex shall take place at least every five years. The Uruguay Round of negotiations reached its final stage in 1994, thus, it was expected that a new round of negotiations would be launched before the end of 1999 or, at the latest, early in 2000 . However, the Seattle Meeting in November 1999 failed to do so.
} 
travel agents to have access to up-to-date information about participating airlines' schedules and fares, and also to make instantaneous bookings. ${ }^{48}$

The GATS members are free to decide upon their commitments with respect to the three services above. Most members made their commitments based on considerations of reciprocity. The EU as a whole has committed itself to opening their markets with respect to all three services listed in the Annex, while the US scheduled a commitment with respect to only one of these services, i.e. aircraft repair and maintenance services. It claimed exemption from the other two services pending further bargaining. ${ }^{49}$ There is thus still much progress to be made before full liberalization is achieved.

\subsubsection{Other commitments of the Member States}

Besides the services discussed above, we should note that some Members have made commitments with respect to other services in the air transport sector. For example, the EU has made commitments on the rental and leasing of aircraft in the "Business Services" section of their schedules under the heading "Rental/leasing services without operators". It is important to note that the GATS principles fully apply to this service since it falls outside the Annex on Air Transport Services. Furthermore, another GATS Annex, on "Movement of Natural Persons Supplying Services Under the Agreement", may similarly be relevant for the personnel involved in the international air transport industry including pilots and flight attendants. ${ }^{50}$

Even under the traditional areas covered by the GATT, given the close connection between transport and goods, there are several subjects with a degree of relevance for the air transport services. For example, the right of transit should be assumed to include the right of air transit, since it does not refer to a specific mode of transportation. Thus, those Countries that have made commitments on transit rights in their national schedules with respect to the trade in goods are obliged to provide the right of air transit, outside the framework of the GATS, but still within that of the WTO.

\footnotetext{
48 B.V.HouTtE, "Community competition law in the air transport sector", 18 Air \& Space Law (1993) 284. In order to avoid conflicts the ICAO revised its "Code of Conduct on the regulation and operation of CRS" which then became the "Code of Conduct for computerized reservation systems". The European Civil Aviation Conference (ECAC) gave its approval to the revision at its meeting of June 1994 in Strasbourg. For the text of the Code, see www.icao.org/icao/en/atb/ecp/ code-conduct.htm. However, since 1994 new ways of CRSs have appeared, entailing new need for clarification.

49 See further the Progress Report (22 Feb.1999) of the PPC Working Group on GATS 2000.

so The Annex applies to measures affecting natural persons who are employed by a service supplier of a member state, with respect to the supply of a service. However, it does not apply to measures affecting natural persons seeking access to the employment market of a Member State, nor does it apply to measures regarding citizenship, residence or employment on permanent basis.
} 


\subsubsection{Dispute settlement}

One distinct improvement brought about by the foundation of the WTO is its new dispute settlement mechanism, designated as the most important single contribution of the WTO to the stability of the global economy. The Understanding on Rules and Procedures Governing the Settlement of Disputes, incorporating a streamlined dispute settlement mechanism, emerged out of the Uruguay Round of negotiations and is a key text $\mathrm{t}^{51}$ for our subject.

The mechanism starts with bilateral consultations. The Members in dispute are offered the chance to meet and try to find ways to reconcile their conflicting interests. If the consultations yield no results, it is open for both parties to ask for a panel with clear terms of reference and an agreed composition to be appointed by the Dispute Settlement Body (DSB). Even after a panel report has been adopted by the DSB, either party is entitled to appeal on points of law. The defeated Member must within a reasonable period either comply with the report of the panel or the appellate body as adopted by the DSB, or must enter into new negotiations with the prevailing Member to reach agreement on a mutually acceptable form of compensation pending actual implementation. As a last resort, the DSB can authorize retaliatory measures against the losing party. ${ }^{52}$

From this summary description it can be seen that the new mechanism tries to resolve a dispute while maintaining friendly relations between the disputing parties and is more flexible and timely than, and constitutes a great improvement on, the former [GATT] mechanism. ${ }^{53}$

Where air transport services are concerned, the situation is more complex. Thousands of bilateral agreements exist between GATS Members, all providing dispute settlement mechanisms in one way or another. Prior to GATS, all these mechanisms under bilateral agreements and under the Chicago Convention operated smoothly. It is not easy to adopt another mechanism within a short period: furthermore, many Members still have reservations on the function of the WTO in the air transport sector. Paragraph 5 of the Annex on Air Transport Services on periodical review reflects this need for a longer

\footnotetext{
51 The Understanding is contained in Annex 2 to the Marrakech Agreement establishing the World Trade Organization. Text in The Results of the Uruguay Round of Multilateral Trade Negotiations: The Legal Texts (World Trade Organization, 1994) 404-433, and at http://www.wto.org/wto/services/ 14_disp.htm.

${ }_{22}$ See Settling disputes: the WTO's most individual contribution, at <http://www.wto.org/about/ disputel.htm>.

53 See, for various opinions on the WTO mechanism of dispute settlement, inter alia, L.WANG, "Some observations on the dispute settlement system in the World Trade Organization", 29 JWT (1995); E.VERMULST and B.DRIESSEN, "An overview of the WTO dispute settlement system and its relationship with the Uruguay Round agreements: nice on paper but too much stress for the system?", 29 JWT (1995); P.T.B.KOHONA, "Dispute resolution under the World Trade Organization: an overview", 28 JWT (1994); N.KOMURO, “ The WTO dispute settlement mechanism: coverage and procedures of the WTO Understanding", 29 JWT (1995).
} 
time to accomplish the drastic change of mechanism and to allow the members to adjust.

Accordingly, if a dispute arises with respect to activities excluded from coverage by GATS under Paragraph 2 of the Annex on Air Transport Services, it is suggested that the dispute settlement procedure provided in bilateral air services agreements or under the Chicago Convention should apply.

With respect to the services to which the Annex is applicable (listed in Paragraph 3), the dispute settlement mechanism of the WTO may of course be invoked, but only so far as the parties concerned have assumed obligations or commitments and, in the light of the above, when the dispute settlement procedures provided for in bilateral air services agreements or under the Chicago Convention have been exhausted. Thus, the new dispute settlement mechanism is in fact supplementary in its nature, with a fair possibility of never being used by the Members. This results in awkward situations that might be detrimental to further liberalization in a multilateral context and that might encourage forum shopping.

\subsection{Comments on the Annex}

Internationalization of the legal framework of civil aviation, at least conceptually, reached an unprecedented level through the inclusion of air transport services in the GATS. ${ }^{54}$ However, it is clear from the foregoing analysis that only a marginal part of these services was included in the WTO framework and even in these areas many problems remained. First of all, further clarification of the services covered is needed. Among other things, the lack of a definition of "services directly related to the exercise of traffic rights" is a striking problem. Although a definition of "traffic rights" is provided in Paragraph 6 item (d) of the Annex, ${ }^{55}$ there is confusion about the phrase "directly related". This can cause uncertainty in the status of the following services: services auxiliary to all forms of transport such as handling and storage, services that are rendered to passenger flights, and ancillary services of air transport.

A further factor is that developments in technology are matched by rapid achievements in the air transport sector. In the face of innovations, the old structure needs to be reviewed and necessary modifications made to meet each new situation. Several years have passed since the Annex was concluded

\footnotetext{
${ }^{54}$ See GATT Uruguay Round of Multilateral Trade Negotiations (H.R.Doc.No.195, 103d Cong., 1994).

55 Para 6 item (d) reads:"'traffic rights' mean the right for scheduled and non-scheduled services to operate and/or to carry passengers, cargo and mail for remuneration or hire from, to, within, or over the territory of a Member, including points to be served, routes to be operated, types of traffic to be carried, capacity to be provided, tariffs to be charged and their conditions, and criteria for designation of airlines, including such criteria as number, ownership, and control."
} 
and during this period significant changes have taken place in the air transport industry. As a result various provisions of the Annex have already become outdated or inadequate. For example, in the field of CRS services the classical pattern has been evolving with the prevalent use of the Internet, thus invoking the necessary accommodation of this new trend.

Given the situation at the time of the negotiations, when air transport services were still governed by the ICAO and the bilateral system, the introduction of multilateral liberalization in this sector really was a revolution; yet even if viewed from a perspective of optimism, the Annex has constituted more a symbol of than an agreement on liberalization. Many delegates stubbornly opposed the inclusion of the sector into the WTO framework. The Annex was adopted only after long deliberations and inter-sectoral exchanges. However, it has proved the possibility of including the sector into a general services framework. Most notably, a periodic review system was set up for further negotiations. The importance of the Annex lies not in the document itself, but rather in what it represents. Thus, it could be extolled for its "pioneer" function in the air transport sector, paving the way for further liberalization. In this sense, it is more important than any other existing agreement relating to the sector.

\section{A FRAMEWORK FOR FUTURE NEGOTIATIONS ON AIR TRANSPORT SERVICES}

\subsection{General observations}

It has been frequently claimed that the present structure of air transport services is rather limited and that much still needs to be done in order to realize genuine liberalization in the sector. The Annex on Air Transport Services may serve as a starting point for these efforts.

Different interest groups have already been preparing new areas for further rounds of negotiation. Although doubts still exist about the inclusion of the sector into the WTO forum, the positive forces have gained the upper hand. Especially, the US and the EU act as the forerunners of liberalization. They have actively advocated the benefits of liberalization and have taken practical steps in determining which areas to open next. ${ }^{56}$

It is widely believed that it is neither possible nor practical to open the whole sector completely in the next round. A more pragmatic way might be to go step by step, using the policy of "nibbling" - as displayed by the Annex on Air Transport Services, gradually realizing the overall liberalization of the sector. Considering the present level of opposition, this may be the only

\footnotetext{
56 On 20 October 1998, the European Commission distributed "GATS 2000 - Questionnaire on $E U$ industry priorities for market opening worldwide", by way of preparing for negotiations in the next round.
} 
effective way to encourage more Members to sit down around the negotiation table. Thus, in dealing with the liberalization of air transport services, there should be both short term and long-term goals. We should first determine the services that are urgently needed and which are feasible for negotiations in the next round, and only afterwards pursue the ultimate liberalization in air transport services. In the following part, we shall tentatively explore possible areas for negotiation in the next round and onwards.

Generally speaking, a further application of the GATS to air transport services could be achieved in the following two ways: (1) removing the possibility of exemptions from the MFN principle and making new commitments to market access for the three services covered in the Annex on Air Transport Services; (2) making new commitments on other services not yet covered. The next round of negotiations could serve as a vehicle for either or both types of expansion in the application of the GATS. ${ }^{57}$

\subsection{Possible areas for liberalization in the next round}

Air transport services include a wide variety of services, each of which needs to be addressed individually in the context of GATS.

At present, three of these services are already covered by the GATS. Air traffic rights, on the one hand, are not covered, although they are in fact the tools used for selling and marketing air transport services, on the other, and the two are thus inextricably linked. Excluding air traffic rights from the GATS is in fact a contradiction. ${ }^{58}$ Further, we can see from the Uruguay Round of negotiations that the greatest problem lies in the basic principles of the GATS. If this can be resolved, ultimate liberalization could be realized within a foreseeable future. However, it will not be easy for future negotiators to reach common ground in modifying the application of these principles, since these constitute the basis of the GATS framework. In the event of failure there should still be another, more practical, way: negotiating one service at a time, starting from the most feasible. In fact it seems unlikely that worldwide consensus on any wide-ranging liberalization of trade in air transport services through the GATS can be obtained as soon as in the next round of WTO negotiations. On the other hand, it seems equally unlikely that there will be general consensus on maintaining the status quo of the present, very limited, GATS liberalization measures in the field of air transport. ${ }^{59}$ It may

\footnotetext{
57 Regulation of International Air Transport Services (report by the Council of Trade in Services, ICAO Working Paper, A32-WP/52, EC/5, 15 July 1998).

${ }^{58}$ See further R.I.R.ABEYRATNE, "Would competition in commercial aviation ever fit into the World Trade Organization?", 61 Journal of Air and Space Law (1996) 835.

59 See further Subject: GATS 2000 - preparations for next round of trade negotiations (by AEA, PPC No.99.03, issued 22 February 1999).
} 
be expected that this dissatisfaction with the status quo will prevail in the next round of negotiations.

\subsubsection{Clarification of certain terms}

The Annex on Air Transport Services was intended to serve as a determination of the scope of application of the GATS in this sector. It sets out to do so by using positive and negative lists of services and, furthermore, extra definitions of four important terms. However, this has not prevented ambiguity. The wording in the Annex has given rise to several reasonable interpretations. Besides, as a result of technical developments, new services have arisen under the three services covered and are causing new applicability problems. $^{60}$ Thus, further clarification regarding the applicability of the Annex is called for. A question that could arise is, inter alia, whether the remittance of earnings services belongs to the marketing and selling of air transport services. Another question deals with the right to use expatriate staff; many other questions may be anticipated.

\subsubsection{Applicable general principles and traffic rights}

As discussed above, the fundamental principle governing the GATS is the MFN principle intended to apply to all parties immediately and in all services covered by the GATS, regardless of the sectors in which specific commitments have been made. ${ }^{61}$ It is possible to limit or exempt MFN, but only at the moment of signing up to the GATS, and these exemptions and limitations are due for a regular review. The principle has been working fairly well in other sectors. For example, it is generally admitted that in the case of GATT side agreements, non-parties to such agreements who are, however, parties to GATT may benefit indirectly from the provisions of those agreements, since treatment accorded to countries under the side agreement may have to be given to all GATT members pursuant to the MFN principle. ${ }^{6}$ Moreover, the cross-sectoral reciprocity inherent in the GATS system gives other States the possibility of benefiting from the comparative advantage which one State may enjoy with respect to the production and marketing of

\footnotetext{
${ }^{60}$ For instance, a common, standardized database for all CRSs to enter freely may be required for interlining purposes. Besides, new concerns are being raised over display bias and abusive booking fees in connection with multi-carrier Internet booking sites that use CRSs for the booking engine. See J.W.YouNG, “Airline alliance - is competition at the crossroads?”, 24 ASL (1999) 287.

${ }^{61}$ The European Commission's informative non-paper on general issues relevant to the discussion on air transport and GATS 2000.

${ }^{62}$ See further W.J.DAVEY, "An overview of the General Agreement on Tariffs and Trade", in E.PETERSMANN and M.HILF (eds.), The new GATT Round of Multilateral Trade Negotiations (1988) 19.
} 
a certain good or service. ${ }^{63}$ However, when it comes to the sector of air transport, this has aroused strong objection, particularly from the ICAO.

The problem in the field of air transport is that the unconditional application of the MFN clause to air traffic rights is incompatible with the current treatment of international air transport based on reciprocity. The MFN rule requires a State to grant to all members the same degree of access to its market, regardless of whether that State's airlines have access to the other markets: such granting of access would cause disparity of air transport markets. ${ }^{64}$ Thus, it is difficult to grant MFN treatment in respect of Third, Fourth and Fifth Freedom traffic rights, ${ }^{65}$ and in respect of freedom of capacity and frequency on all routes to/from a specific country. It has been suggested that the ultimate and thus final solution that could satisfy opposition to the inclusion of air transport services into the GATS framework would consist of changing the method of applying the MFN principle to air traffic rights. A number of experts have proposed that the MFN principle should oblige every Member to offer to all other Members the same conditions that it already offers in its most favourable bilateral agreement; this should occur on the basis of reciprocity and, therefore, in exchange for the same condition's being imposed on the other party to the agreement. ${ }^{66}$ Through this mode of application of the MFN principle one could prevent countries from taking advantage of the MFN principle without offering reciprocal conditions. ${ }^{67}$ Proponents of this approach have argued that it would set in motion a mechanism for progressive multilateral liberalization.

It cannot be denied that air transport services are different from other services in some significant respects. Progressive liberalization in different sectors involves different market structures and results in different consequences of the application of the MFN principle. The potentially absurd

${ }^{63}$ H.A.WASSENBERGH, "The future of international air transportation law: a philosophy of law and the need for reform of the economic regulation of international air transport in the 21 st century", 20 Annals of Air and Space Law (1995) 406.

${ }^{64}$ See further STOCKFISH, loc.cit.n.3, at 641.

${ }_{65}$ The Third Freedom refers to the right to discharge traffic from the home country in a foreign country; the Fourth Freedom is the right to pick up traffic in a foreign country bound for the home country; and the Fifth is the right to pick up traffic in a foreign country and convey them to yet another country, provided that the flight originates or terminates in the home country.

${ }^{66}$ Actually, it is not precisely true that the GATS offers no place for the operation of reciprocity. It has even been claimed that during the Uruguay Round the position of reciprocity took gained prevalence. See T.TAKIGAWA, "The impact of the WTO Telecommunications Agreement on US and Japanese telecommunications regulations", 32 Journal of World Trade Law (1998) 43. The case of recognition of qualifications under Art.VII GATS and of recognition of foreign prudential regulation of financial services is instructive. See further JANDA, loc.cit.n.33, at 420-421. Furthermore, the MFN Principle also applies to concessions that are granted to non-GATS Members, e.g. on a bilateral basis.

67 VIRGINIA RODRIGUEZ SERRANO, "GATS Annex on Air Transport Services, its shortcomings and possible revision", and R.JANDA, "Government Regulation of Air Transport", 19 February 1999, at http://www.law.mcgill.ca/academics/coursenotes/janda/grat/virginia.html. 
results of an inappropriate application of the MFN principle in the field of air transport services should not have the effect of ruling out the possibility of a modified application of this principle in this specific sector. Thus, as suggested above, it is realistic to consider incorporating the notion of reciprocal exchange of equal access into the definition of hard rights, thus combining existing bilateralism with the MFN principle. The MFN principle would in this way be coupled with commitments on market access, establishing a threshold of liberalization beneath which a member is not allowed to go. Over time, this would evolve into a plurilateral, and ultimately a truly multilateral, arrangement. ${ }^{68}$

There is also controversy on the application of National Treatment principle. It is said that, as is the case with the MFN principle, the National Treatment principle too is inappropriate for application to air transport, which should rather be based on balance of economic benefits. This view is championed by the US in particular. It has, however, been refuted as inappropriate from the perspective of global trade liberalization. All air transport suppliers should compete on the same conditions, excluding considerations of protectionism. In the field of other services similar claims of non-applicability of the National Treatment principle have also been rejected. Thus, in view of preceding experience the principle is not to be regarded as an obstacle to liberalization in the air transport services.

\subsubsection{Services eligible for negotiation in the next Round}

There has been some discussion about other services to be included in the future negotiations. The ICAO has invited experts to pursue research into further liberalization in the sector and is actively pursuing more active participation in the negotiations. The International Chamber of Commerce (ICC) firmly supports further liberalization in the field of air transport ${ }^{69}$ and its Committee on Air Cargo Transport has formulated a Policy Statement on Air Cargo and the WTO to define its position. ${ }^{70}$ The US concern about the new negotiations has manifested itself in proposals on further liberalization in the sector. The EU has the highest number of stakes and is, consequently, even more active in this field. European organizations have, at various levels, been responding positively to negotiations on the subject. The European Commission launched a comprehensive process of gathering information from the member states and from representatives of the European industry, including the air transport industry, while organizing a special seminar on "Air

\footnotetext{
${ }^{68}$ See further JANDA, loc.cit.n.3, at 424-425.

69 See further Convergence of competition law and policy in the field of air transport with special reference to the EU-US context (Commission on Air Transport of the ICC, 16 July 1997), http:// www.iccwbo.org/Cust/html/310468e.htm.

70 International Chamber of Commerce, Doc.No.322-3/5 Rev.3 (25 September 1998).
} 
Transport in GATS 2000". ${ }^{71}$ A professional organization - the European Services Network (ESN) - was set up and a work programme in relation to the GATS 2000 seminar was developed. The Association of European Airlines (AEA) was also involved in the GATS 2000 preparations $^{72}$ and the European Express Organization issued a "Position Statement" regarding the inclusion of postal and express delivery services in the GATS. ${ }^{73}$ Still other European organizations are and will also be most interested in the liberalization of the sector. Whatever services the efforts may concern, there is a common understanding that overall liberalization is remote. For the time being, the workable way is to identify several services for consideration. These services will be addressed in the following sections.

\subsubsection{Freedom of transit}

The right of transit has been defined as the First and Second Freedoms: the right to fly over another country without landing and the right to make a technical stop without picking up or letting off revenue traffic. ${ }^{74}$ These two freedoms enable market access in other countries, facilitate the provision of air transport services, and form the basis of international trade in the field of air transport. On the other hand, the exercise of the freedoms does not affect the commercial interests of the state concerned. Accordingly, these two freedoms cannot be considered to constitute economic assets to be exploited by national governments. ${ }^{75}$ Moreover, the freedoms have in fact been indirectly included in the GATT under the commitment of the right of transit. What we need to do in a new round of negotiations is merely specify the matter and emphasize it to the member states. It will, therefore, be an easy item and should be given priority in future negotiations. Actually, there is already an agreement on the subject, viz. the International Air Services Transit Agreement of $1944,{ }^{76}$ but this agreement is not widely ratified and is in force among only ten States, ${ }^{77}$ hence its limited validity and social impact. It

71 This Seminar was held on 20 April 1999 in Brussels to stimulate discussion of the subject.

72 The AEA, on the one hand, participates with other industries from the services sector in the ESN while, on the other hand, a PPC w/g is developing proposals on a possible extension of the scope of the GATS in the air transport sector.

${ }^{73}$ Position Statement of the European Express Organization Regarding the Inclusion of Postal \& Express Delivery Services in GATS 2000 (1 April 1999), at Http://www.euroexprss.org.

74 The concept of "freedom of the air" was formulated by the Canadian delegation at the Chicago Conference. See A.F.LOWENFELD, Aviation law: cases and materials (1981) 2-6.

${ }^{75}$ Market Access/Traffic Rights in GATS 2000 (European Commission non-paper, RJF, 29 March 1999).

${ }^{76}$ This Agreement was signed at Chicago on 7 December 1944. See: http://www.lawbusiness.ch/ chicago/transit.html.

77 P.M.DE LEON, "Air transport as a service under the Chicago Convention: the origins of cabotage", 19 Annals of Air and Space Law (1994) 534-535. 
should be possible to take several provisions of this Agreement and use them as a basis in future negotiations. ${ }^{78}$

\subsubsection{Non-scheduled (charter) flights}

The development over the years of increasingly flexible charter rules has progressively led to an erosion of the regulatory distinction between scheduled services and non-scheduled flights. Although Article 5 of the Chicago Convention states that airlines shall be granted the "privilege" of operating nonscheduled services, it also allows states to attach whatever conditions or restrictions they see fit. In practice, some countries have sought to apply such restrictions, for example, by including charter flights within their bilateral air services agreements. The ICAO has pointed out that a discussion about including commitments with respect to non-scheduled services in the Annex could be conducted on the basis of some provisions on market access that appear in bilateral agreements. Considering the close relationship between scheduled and non-scheduled services, it is believed that liberalizing the nonscheduled services would be the first step towards the liberalization of scheduled services.

\subsubsection{Air cargo services}

Air cargo is becoming an increasingly important part of the international logistic chain serving trade and industry all over the world. Although, in terms of weight, only two percent of all cargo moves by air, its value accounts for well over a third of all the world trade in merchandise. ${ }^{79}$ It represents an essential service for the latter's infrastructure, and the more efficient are the means of transport of a country, the better its system of exports (and imports) works. Air cargo is an industry distinct from passenger services, which are much more subjected to political considerations and the idea of balance of economic benefits.

Air cargo services are closely connected with other modes of transportation, and the fact is that all other means of transportation have been undergoing proper liberalization. As a result inter-modal transportation will never be successful as long as air cargo still remains under its old regime: this has an unwieldy structure that obstructs the forming of further links among different means of transportation. Failing to improve the structure would thwart the liberalization of trade in goods and other services and, in the end, harm the consumers' interests.

It is to be noted that the real possibility that liberalization may occur lies in the fact that there is not much sense in restricting a certain means of

\footnotetext{
${ }^{78}$ For example, Arts.I (secs. 1 and 4) and II (sec.1) of the International Air Transit Agreement could provide the basis for an appropriate definition of these two operational freedoms.

79 Op.cit.n.70.
} 
transport when barriers for the entry of goods are progressively lifted in many countries. This provides the fundamental premise for possible liberalization. However, as we have witnessed, the air transport component of air cargo services is still strongly linked with passenger transport services, while it is still difficult to persuade states to make certain commitments in respect of passenger services at this stage. Since traffic rights are generally less important an issue as far as cargo services are concerned, it has been suggested that the latter be included in the GATS either by focusing on services specifically provided by all-cargo transport aircraft or by adopting an even broader approach that covers all types of cargo operation by air. ${ }^{80}$ This might stimulate further liberalization in cargo transportation and serve as breakthrough point for the liberalization of traffic rights.

\subsubsection{Ownership and control}

Airlines are traditionally a symbol of a State's sovereignty. The relevance of aircraft to the State in times of war has always justified the special status of airlines and aircraft. ${ }^{81}$ It has been said that civil aviation has become a part of the face of the state. ${ }^{82}$ Indeed, the situation of airlines to a certain extent mirrors the situation of a state. States are thus most interested in protecting national airlines through special measures. The most outright measure is to impose limitations on ownership and control. Actually, suggestions have been made regarding the modification of the traditional criteria of ownership and control, in order to facilitate market access. This would broaden the investment possibilities for carriers and thus increase competition in realizing maximum resources allocation. ${ }^{83}$

Formerly, most bilateral air transport agreements contained clauses allowing states to refuse recognition of a designation of air carriers that are not substantially owned and effectively controlled by nationals of the designating party to the agreement. This was justified by the concept of sovereignty and also by the fear of such possibilities as the dissemination of military and technological secrets, having foreign aircraft in the civil reserve air fleet (CRAF), and terrorism. ${ }^{84}$ All this has served to imbue airlines with an artifi-

\footnotetext{
${ }^{80}$ Air Cargo - Issues that could be raised in GATS 2000 (European Commission non-paper, RJF, 29 March 1999).

81 B.J.H.CRANS, "Liberalization of airports", 21 Air \& Space Law (1996) 10.

82 See further H.A.WASSENBERGH, "Regulatory reform - a challenge to intergovernmental civil aviation conferences", 11 Air Law (1986) 31.

${ }^{83}$ See further R.DOGANIS, "Relaxing airline ownership and investment rules", 21 Air \& Space Law (1996) 267.

${ }^{84}$ See further B.M.J.SwINNEN, "An opportunity for trans-Atlantic civil aviation: from open skies to open markets?", 63 Journal of Air Law and Commerce (1997) 282.
} 
cial sense of "nationality" ${ }^{85}$ The restriction has been abolished among EU member states. The so-called "de-nationalization" has become the modern trend, which means the elimination of the "nationality" criterion for the authorization of designated air carriers, as governments do not wish to interfere with economic aspects of the airline industry. ${ }^{86}$ A European Civil Aviation Conference (ECAC) ${ }^{87}$ task force recently developed a draft recommendation to replace the traditional ownership/control clause in bilateral air services agreements with a clause stipulating the requirement of a strong link between an airline and its designating State. ${ }^{88}$ Under this recommendation, an airline would be required to be established and have its principal place of business in the country of designation, and to hold an Air Operator's Certificate (AOC) from that State. The former criterion -- the nationality of the owners and managers of the airline - is thus no longer relevant. ${ }^{89}$ Conceivably, the new concept could be multilateralized through the GATS, provided appropriate negotiating safeguards apply in the prevention of a one-sided outcome. On this point, use could be made of Article XVI of the GATS that, inter alia, establishes rules against the avoidance of commitments of market access. Among these rules is the prohibition of limiting participation of foreign capital in terms of maximum percentage of foreign shareholding.

The abolition of the nationality criterion might involve a risk of "flags of convenience" unless certain harmonization efforts are included in the general policy approach..$^{90}$ Nevertheless, the main effect of liberalizing the ownership conditions would be to open the possibilities of international mergers, thereby creating the possibility of truly global networks. ${ }^{91}$

\footnotetext{
${ }^{85}$ See further Z.J.GERTLER, "Nationality of airlines: a hidden force in the international air regulation equation", 48 Journal of Air Law and Commerce (1982) 51.

${ }^{86}$ H.A.WASSENBERGH, "International air transport: regulatory approaches in the nineties", 17 Air \& Space Law (1992) 68.

${ }^{87}$ The ECAC is an inter-governmental organization founded in 1955. It aims at promoting the continued development of a safe, efficient and sustainable European air transport system. See further http://www.ecac-ceac.org/uk.

${ }_{88}$ See further PPC paper 99.01.

89 The register of Australia is basically a nationality register not intended to have any role as a register of title and charges. This division also serves a good example. See further W.KoECK, "Introduction to importation, acquisition and financing of aircraft in Australia", 11 Air Law (1986) 19.

90 See Regulation of International Air Transport Services, Broadening Airline Ownership and Control Criteria (ITF Civil Aviation Section, Working Paper 87), http://www.itf.org.uk/SECTIONS/ $\mathrm{Ca} / 87 . \mathrm{htm}$.

91 The European Commission non-paper on Ownership/Control, FS, 9 April 1999.
} 


\subsubsection{Ground handling}

During the Uruguay Round of negotiations, ground services were initially included in the draft Annex on Air Transport Services, but were later deleted since many members either filed exemptions from the MFN principle or maintained reservations and limitations. ${ }^{92}$ Ground services are the starting point and the finishing point of air transport services. They constitute the basis for the exercise of other air transport services, particularly the exercise of traffic rights. Liberalization of the ground services is conducive to further negotiations on traffic rights. To a certain extent, ground handling services are similar in their character to the three services covered by the Annex as auxiliary services and as such constitute the area most susceptible to liberalization without arousing much opposition.

The problems relating to ground services reside in prevailing restrictions on their handling by the carriers themselves and the absence of competition between independent handling companies. In order to guarantee quality services at an acceptable price level, discriminatory practices and distortions of competition must be abolished and their reappearance prevented in the future by removing current de jure and de facto restrictions on free access to the market. ${ }^{93}$ Against this backdrop the ICAO introduced an element of liberalization by offering the possibility of letting carriers operate their own activities, individually or with other airlines, or to select a provider for themselves. ${ }^{94}$ This has now been introduced as a regular item in bilateral instruments.

Ground handling is a very broad sector including different types of services that need to be distinguished. ${ }^{95}$ Liberalization in this area opens up safety-sensitive activities and puts new competitive pressures on the relevant companies, influencing the safety culture required in the air transport industry and, consequently, requiring the adoption of safeguard measures with minimum safety standards for ground handling operators. ${ }^{96}$

\footnotetext{
92 Doing Business/Ancillary Issues in GATS 2000 (European Commission non-paper, RJF, 3 April 1999).

93 C.DUSSART-LEFRET and C.FEDERLIN, "Ground handling services and EC competition rules: a Commission initiative to open up ground handling markets", 19 Air \& Space Law (1994) 59; see also R.PADOVA, "Deregulation and competition of ground handling services in EU airports an Italian perspective", 22 Air \& Space Law (1997) 203; W.DESELAERS, "Liberalization of ground handling services at Community airports", 21 Air \& Space Law (1996) 260.

94 ICAO doc.AT Conf/4-WP/14 (17 May 1994).

${ }^{95}$ For example, servicing and attending aircraft is different from airport management and air traffic control services. See further supra n.50.

${ }^{96} \mathrm{http}: / /$ www.itf.org.uk/SECTIONS/Ca/55.htm.
} 


\subsubsection{Aircraft leasing}

Both wet and dry leasing are increasingly important in today's air transport industry. Lease arrangements have become very common and have enhanced the utilization of costly aircraft. ${ }^{97}$ As indicated earlier, some GATS members have made commitments on rental/leasing services without operators, a socalled "dry" leasing service. No commitments have, however, been made yet concerning "wet" leasing services, which might significantly contribute to improving an airline's operating efficiency.

The overall status of aircraft leasing in the GATS is not yet clear. Some Countries still adopt a very restrictive approach to leasing. This may be caused by a lack of clarity about which State retains operational control of the leased aircraft, as well as differences in safety oversight requirements, which are necessary to ensure aviation security. Clarity could be improved within the framework of GATS. The principle of transparency may imply an obligation to disclose relevant information and to avoid possible unclear areas.

It may be concluded that the sector can be covered by the GATS, with due account being taken of aviation safety and national security. This could be achieved through clear-cut but sufficiently flexible conditions for the title registration, ${ }^{98}$ the maximum duration of wet leases and/or the maximum percentage of wet-leased aircraft in an airline's fleet. ${ }^{99}$

\subsubsection{Other services and the way forward}

Besides the aforementioned services various interest groups have raised other services as subjects for further negotiation, such as airport charges, code sharing, ${ }^{100}$ slot allocation, express delivery services, etc. The feasibility of their coverage is still being considered.

\footnotetext{
97 G.F.FITZGERALD, "Convention on international civil aviation: lease, charter and interchange of aircraft in international operations", 1 Air Law (1975/1976) 20.

98 For discussion on title registration, see R.J.GOLDSTEIN, "Aircraft title registration and perfection of lien rights in aircraft", 4 Air Law (1979) 2-4; M.J.LESTER, "Aircraft interchange", 4 Air Law (1979) 9.

99 See further Economic and Regulatory, athttp://www.ecac-ceac.org/uk/activities/activities-eco nomic.htm.

${ }^{100}$ Code sharing is important for the effective participation of all states. One of the obvious ways for strong air carriers to enable weaker air carriers of foreign states to operate their own international air services is to negotiate a code-sharing arrangement with the foreign air carrier.
} 


\section{CONCLUSION}

\subsection{Tentative evaluation}

Civil aviation is unique in that it has up to now largely remained regulated at the international level by bilateral agreements. ${ }^{101}$ The effects of the Uruguay Round on the liberalization of international trade in air transport services so far have been rather limited. The GATS and the Annex on Air Transport Services cover only a limited range of affiliated aviation services, while many other aviation services, including the exercise of various "hard" and "soft" rights, are not yet included. In essence, the GATS and the Annex codify the status quo and have established a mechanism for future rounds of negotiations for this sector of services. The actual degree of liberalization has remained dependent on the commitments that states are willing to accept for inclusion into their Schedules. As most countries still have misgivings about the WTO framework for air transport services, it is unlikely that many new markets will soon be opened to competition on the global level.

This paper has revealed the complexity of the integration of the Annex with the Articles of the GATS agreement and the way in which the compromise reached during the negotiations of the Group of Negotiations on Services (GNS) is reflected in the Annex. ${ }^{102}$ The reluctance of the members to include hard rights in the GATS can be largely explained by the fear that unbalanced market gains may result from undertaking different commitments governed by the MFN principle. There is a tendency to demand reciprocal treatment, at least for initial market access. It is difficult at the moment to predict the likely outcome of the next round of negotiations. For the EU, the negotiations are closely linked with its internal timetable on the liberalization of air transport services; for the US, the negotiations are closely related to its own economic expansion. In spite of the existing resistance to further liberalization, the advantages of an agreement under the GATS regime, if compared with other, bilateral or regional options, are obvious. For the time being, there is in fact no choice but that of liberalizing within the framework of the GATS.

\subsection{Implications for developing countries}

In the negotiations on the different sectors the possible impact of liberalization on developing countries received special attention. Account was taken of their special needs, particularly the possibility of achieving maximal

\footnotetext{
101 C.LYLE, "Plan for guiding civil aviation in the 21 st century represents a renewed commitment by ICAO", ICAO Journal, March 1997, http://www.icao.org/icao/en/jr/5202_ar.htm.

102 A.MENCIK VON ZEBINSKY, "The General Agreement on Trade in Services: its implications for air transport”, 18 Annals of Air and Space Law (1993) 398.
} 
benefits from their participation. It is necessary for developing countries effectively to participate in the air transport industry while retaining economic independence. ${ }^{103}$ It has been widely recognized that freedom of trade should be moulded into freedom to co-operate and that during the time needed for weaker national air carriers to become internationally competitive, the rules should be interpreted and applied in a pragmatic and modern way. ${ }^{104}$

A classic objection to the application of the GATS concerns its possible destructive effects on the economic development and independence of developing countries. Air transport is one of the three objectives that new nations seek to achieve on gaining independence: a central bank, a seat at the UN and a national airline, ${ }^{105}$ hence its sensitivity. As developing countries lag behind in the sector, the consequence of competition may be the eclipse of the national airlines from the market and the total dependence of national aviation on foreign suppliers. This would be detrimental to national economic independence and national security. Therefore, the developing countries should be cautious so as to avoid losing control over national development.

In view of all these factors the GATS and the WTO Final Act contain special rules relating to developing countries. First of all, the developing countries may take advantage of exemptions from the MFN principle in order to maintain restrictive market access. The Understanding on Rules and Procedures Governing the Settlement of Disputes also provides several preferential measures for developing countries. ${ }^{106}$ Furthermore, Article IV of the GATS contains incentives for increased participation of developing countries. The Decision on Measures in Favor of Least Developed Countries, ${ }^{107}$ forming part of the Final Act of the GATS, establishes preferential treatment for these countries. Thus, it is possible for developing countries to make exceptions to market access or to establish preferential measures. If they choose, they can maintain restricted access to their markets and use these preferential treatments to help adjust to a more competitive environment.

\footnotetext{
${ }^{103}$ This concern has been frequently asserted by developing countries. See further: The Arab States' position on the regulatory frameworks for international air transport (ICAO, AT Conf/4-WP/89, 30 Nov. 1994); see also the position of the 42 African states, in ICAO doc.AT Conf/4-WP/66 (20 Oct.1994) and of the 16 Latin American and Caribbean States, ICAO, doc.AT Conf/4-WP/90 (30 Nov.1994).

104 H.A.WASSENBERGH, "De-regulation of competition in international air transport", 21 Air \& Space Law (1996) 88.

${ }_{105}$ R.S.SOWTER, "Lease finance for airlines", 4 Air Law (1979) 12.

106 The Understanding constitutes Annex 2 of the Marrakech Agreement Establishing the World Trade Organization. For example, Art.4 (10) specifies "During consultations Members should give special attention to the particular problems and interests of developing country Members". In particular, Art.12 (11) provides that the panel report shall explicitly indicate the form in which account has been taken of relevant provisions on differential and more-favourable treatment for developing Members.

${ }^{107}$ This is a Ministerial Decision adopted by the Trade Negotiations Committee on 15 December 1993.
} 
Developing countries are standing at the gateway into a new era. With their commitments to open their markets and to compete with international suppliers, they face a great challenge. First of all, they have to accept the fact that liberalization is well underway and that no one can obstruct its progress; secondly, they urgently need to develop an operable domestic regulatory policy and an independent regulatory body to overlook the performance of commercial actors; thirdly, they are in great need of experts in the field of aviation and international trade to help adjust national policy and achieve a healthy economic development. The transitional period will be hard in the beginning but could serve as a good opportunity. Developing countries should maximize the benefits of the internationalization of services and move on towards the fast-changing information age.

\subsection{Closer cooperation between the ICAO and the WTO}

A final important item to be dealt with here is the need to clarify the relationship between the regime on air transport services under the auspices of the WTO and the closely connected work of the ICAO as the first multilateral organization in the field. The ICAO is endowed with a broad and precise legislative mandate in the technical field of aviation ${ }^{108}$ and a more vague mandate on its economic, regulatory and trade related aspects. In the economic field the ICAO has proved to be unable to provide the institutional framework for the elimination of discrimination and the reduction of barriers in the international trade of air transport services. The WTO, on the other hand, is a specific organization in this field, one that has gained a vast amount of experience and expertise in the international management of trade liberalization and is thus clearly the right forum for the economic side of air transport services. Thus, it has been suggested that the ICAO be in charge of the technical field of the sector and the WTO take the responsibility of the economic field. ${ }^{109}$ However, being a technique-intensive industry, it is impossible completely to separate the economic side of air transport from its technical side. Consequently, in the above structure close cooperation between the two aspects is desirable. ICAO involvement in trade in services started at the first Air Transport Conference in 1977, where this issue was first

\footnotetext{
108 Traditionally, aero-politics have focused more on air transportation, but, actually, the ICAO has also dealt with air navigation, which actually gave the ICAO its face. See S.A.KAISER, "Infrastructure, airspace and automation: air navigation issues for the $21^{\text {st }}$ Century", 20 Annals of Air and Space Law (1995) 447.

109 Some authors have suggested three divisions of the air transport industry - the economic side (to be covered by the GATS); the technical side (to be covered by ICAO); and the legal side (to be covered by the Legal Committee of the ICAO).
} 
raised. ${ }^{110}$ Since then, the ICAO has maintained an active interest in the Uruguay Round of negotiations. At the fourth worldwide Air Transport Conference under ICAO auspices in 1994 a multilateral framework was proposed. ${ }^{111}$ Liberalization in air transport services was publicly recognized as the final goal. ${ }^{112}$ This setting of an aim served to provide the impetus towards multilateralism and is in line with the aim of the WTO.

It is clear that the Chicago-based system and the GATS can co-exist. ${ }^{113}$ In fact, they are complementary in their functions. ${ }^{114}$ First of all, air transport services are to be dealt with from various perspectives: technical, economic and legal. Consequently the two organizations with different assignments in the sector should be taken in close combination with one another. Secondly, the ICAO is specialized in the field of air transport services and constitutes a pool of air transport experts; the WTO, on the other hand, needs the expertise, support and advice of the ICAO for its negotiations towards further liberalization. Thirdly, since it is not yet possible to include all services, particularly the "hard" rights, in the WTO framework, the services not yet so covered should temporarily remain under the ICAO regime. In the longer term, however, the WTO will review the Annex on Air Transport Services and, depending on the progress achieved in ICAO, may indeed extend its scope to air transport traffic rights. ${ }^{115}$

Actually, the ICAO has been rather enthusiastic in preparing for the next WTO round of negotiations. It acknowledges that this new Round will be of great importance to the aviation community since it will include a review of air transport services with an eye on expanding application of the

\footnotetext{
${ }^{110}$ See ICAO Council Recommendation 11 (1985) and ICAO General Assembly Resolution A26-14 on trade in services.

111 Regulation of international air transport services, report by the Council on Follow-up Work Requested by the World-wide Air Transport Conference, See further ICAO doc.A32-WP/9, EC/3 (15 May 1998).

${ }^{112}$ See keynote address by A.KOTAITE, president of the ICAO Council, at the session on "Aviation regulation: new millennium - new direction”, 56th IATA Annual General Meeting, Sydney, 5 June 2000, www.icao.int/icao/en/pres/pres_sydney.htm.

113 Some authors have even made a comparison between the constitutional issues of the two organizations. See, for example, MENCIK VON ZEBINSKY, loc.cit. n.108 at 388-390. Such a comparison shows that the economic provisions as contained in the GATS do not appear, or exist to a lesser extent, in the Chicago Convention, confirming that the two organizations regulate different aspects of the matter. Their existence side by side would, consequently, hardly cause conflicts from a constitutional point of view.

114 Signatories to both would have to comply with both. States parties to the GATS would, as part of their transparency obligations, have to record their existing commitments under the Chicago system with the GATS and file them appropriately. Similarly, any GATS commitments not already recorded with ICAO will have to be filed in accordance with ICAO requirements under the terms of the Chicago Convention.

115 See further GIL, loc.cit.n.28, at 80 .
} 
GATS. ${ }^{116}$ A special panel has been set up to deal with this issue and to take a stand on the question of the future framework. The WTO for its part has facilitated these developments. It has afforded observer status to the ICAO and has joined in bringing about a close relationship conducive to a further healthy liberalization of air transport services. ${ }^{117}$ Dr. A.KOTAITE, President of the Council of the ICAO, stated, "[T] he objective of ICAO is to contribute constructively to the WTO process and to ensure that the objectives of the international aviation community continue to be met as the international trade system continues to evolve". ${ }^{118}$ The ICAO should adopt a new and special role in the future negotiations in order to ensure that the particular characteristics of air transport, and its regulatory structures, agreements and arrangements, are fully understood and taken into account. ${ }^{119}$

\subsection{Epilogue}

Compared to the situation in other industries, the level of international cooperation and joint decision-making in the field of air transport services is unprecedented. This cooperative spirit, together with technical innovation and rising consumer demands, has carried the sector to the threshold of a truly global open market. ${ }^{120}$ Confronting the challenge of the twenty-first century, liberalization is unavoidable. We should bravely face this challenge in the quest for a new millennium strategy. In the words of the IATA Director-General PIERRE JEANNIOT, "[t]here is no question that the air transport industry will continue to liberalize. Our main concern is that liberalization proceeds in a manner which produces the best balance of benefits to consumers, airlines and the public interest". ${ }^{121}$ After all, it is the global public interest that will decide on what will have to be done in this new millennium. ${ }^{122}$

\footnotetext{
116 "ICAO adopts position on negotiations in World Trade Organization", ICAO Update, Nov.Dec.1999, http://www.icao.org/icao/en/jr/5409_up.htm.

117 In July 1998 the Council for Trade in Services decided to confer observer status on an ad hoc basis for attending the meetings of the WTO. The ICAO would be able to make recommendations during the negotiations and the WTO would take them into account.

$118 \mathrm{http} / / / \mathrm{www}$.icao.org/icao/en/nr/pio9915.htm.

119 See further M.A.MAGDONA and L.B.MALAGAR, "The implications of the General Agreement on Trade in Services (GATS) on international civil aviation: should we do away with ICAO", 14 The World Bulletin (Special Issue on International Civil Aviation and the Law, Jan.-Apr.1998) 128.

120 J.W.YouNG, "Globalism versus extraterritoriality, consensus versus unilateralism: is there a common ground? A US perspective", 24 Air \& Space Law (1999) 216.

121 P.JEANNIOT (Director-General of IATA), "Balance the benefits of liberalization", at http:// www.iata.org/py/pr99novb.htm.

${ }^{122}$ H.A.WASSENBERGH, "The regulation of state-aid in international air transport", 22 Air \& Space Law (1997) 165.
} 